\title{
An Empirical Investigation of Capital Structure Strategies Adopted by Botswana Firms - An Exploratory Study
}

\author{
Mogotsinyana Mapharing \\ Department of Accounting and Finance \\ University of Botswana \\ P.O. Box 00701, Gaborone, Botswana \\ Simangaliso Biza-Khupe \\ Department of Accounting and Finance \\ University of Botswana \\ P.O. Box 00701, Gaborone, Botswana \\ Sadie K. Sekolokwane \\ Department of Accounting and Finance \\ University of Botswana
}

\begin{abstract}
The paper is set on the theoretical backdrop of the importance and exigency of capital structure in firms' pursuits to maximize shareholders' wealth. The study investigates the different capital structure strategies adopted by Botswana firms. In its methodology, the study adopted an approach used by Graham and Harvey [1] in developing the research instrument. The study methodology used is premised on the presupposition that issues of capital structure are more pronounced with the increase in firm size, with the largest firms generally being those listed on the stock exchange. Primary data was collected from a small sample of firms listed on the Botswana Stock Exchange (BSE), in keeping with the exploratory nature of the study. The results were indicative of lack of theoretical considerations in the adoption and application of capital structure strategies by management across the listed firms. While most firms preferred using external equity as a financing option, followed by retained earnings, debt was found to be the least preferred financing option. Also found was that management was generally knowledgeable of the benefits associated with debt financing, and in particular the tax-deductibility of the cost of debt and reduction of agency costs. Overall, the findings were puzzling when juxtaposed with the theoretical perspectives of the trade-off theory, the pecking order theory and agency costs theory. The study concludes by suggesting further research to uncover the extent to which these preliminary results are applicable and uncovering the underlying rationality.
\end{abstract}

Keywords: Capital structure, Stock Exchange, Equity, Debt, Retained earnings, Exploratory study

\section{INTRODUCTION}

The literature alludes to the role and importance of financial ethos and management in the operations, performance and sustainability of organisations [2, 3]. While financial ethos and financial management, as constructs, cover a wide spectrum, there is considerable consensus in the literature to suggest that capital structure is one of those common-denominator factors that have a multiplier effect in the determination of the performance of other key 
organisational indicators and hence defines organisational dexterity both in the short- and long-term [4,5]. Consequently, the financial soundness of firms and their longevity can be attributable to how aptly an organisation sources and uses its funds, among other factors. In this respect, capital structure is an important subject matter and the research on how firms can improve on, or ideally achieve, optimal capital structure levels, are warranted. Intuitively, the larger the size of a firm the bigger would be the expected marginal returns from an optimal capital structure.

The literature provides a myriad of strategies that firms could potentially adopt to formulate their capital structures, with each strategy bequeathed with its own pros and cons [4]. With the advent of the trade-off condition that exists with the choice of one strategy over another, it would be expected that management engages some cost-benefit method to ascertaining, choosing and adopting a particular capital structure strategy. Moreover, these firms would also be expected to periodically evaluate the efficacy of their chosen strategies and undertake all necessary adjustments.

To the extent that these capital structure strategies are well implemented, the overarching goal would be to maximize shareholders' wealth. However, capital structure and financial performance have been studied worldwide with varied results [6]. For example, the impact of capital structure on financial performance of Ghanaian listed banks reveals that increasing the amount of long-term debt would result in a decrease in the profitability of the firms [6]. Abor [7] examined the effect of capital structure on the financial performance of small and mediumsized enterprises (SMEs) in Ghana and South Africa. The overall results indicate that capital structure, especially long-term and total debt ratios negatively affect performance of SMEs. Within an industry, if a firm maintains high leverage, as such attempting to compete on the basis of innovation, this results in diminished performance [3]. The negative relationship between leverage and profitability has also been documented in other studies [8-11]. Meanwhile, quite a good number of studies have found a positive relationship between debt and profitability [12-14]. However, due to its extensive research, the relationship between capital structure and firm performance is not of much concern in this paper, but rather the nature and form of capital structure strategies or policies adopted by Botswana enterprises.

This paper is a preliminary study on the insights of the decision-makers in considering and determining capital structure strategies. Of particular interest to the study is the degree to which capital structure considerations by decision-makers are aligned to the established theoretical underpinnings of (i) the trade-off theory, (ii) the pecking order hypothesis and (iii) the agency costs theory. The focus of the study is therefore directed at soliciting management insights on their knowledge of the theoretical underpinnings of capital structure and the application of the same.

\section{REVIEW OF RELATED LITERATURE}

Capital structure is defined as the 'the mix of securities and financing sources used by corporations to finance real investment' $[15, \mathrm{p} 81]$. In essence, capital structure refers to the manner in which firm sources all the finances required to fund its operations, fixed assets and investments. Conventionally, the financial instruments used to source funds fall in two broad categories of equity and debt, although the recent past has witnessed an increase in the more complex hybrid instruments. The literature alludes to different reasons why management should prefer one form of financial instrument over another, or a particular combination over another [2]. Overall, different capital structure strategies have different implications to the operations and financial performance of the firm. Next is a discussion of some of the notable theoretical approaches to capital structure strategies. 


\section{Capital Structure}

Capital structure has been a widely researched topic ever since Modigliani and Miller [16]'s seminal work on capital structure irrelevance theory. Modigliani and Miller [16] argued and proved that the choice between debt and equity financing has no material effect on the value of the firm, or on the cost or availability of capital. However, they assumed perfect and frictionless capital markets in which financial innovation would quickly extinguish any deviation from their predicted equilibrium. Even though their assumptions have raised a lot of criticism [17], the logic of their findings has widely been accepted. For example, Naidu [4] submitted that after an intense debate for a period of two decades, it is generally accepted today that the degree of financial leverage is not inconsequential and therefore an optimum capital structure does exist, particularly when taxes, bankruptcy costs and agency costs are considered. As thus, optimal capital structure would involve trade-off between the tax advantage of debt and various leverage related costs. The end result of these model extensions was the recognition that the existence of optimal capital structure is essentially an empirical issue [5].

It is on this backdrop that many researchers were motivated to find evidence of the existence of leverage related costs, which eventually led to determinants of capital structure and its strategies. But then, the overarching question is how well defined are capital structure strategies adopted by firms' and 'can these strategies be explained by existing theories'?

\section{Theoretical Considerations}

Modigliani and Miller [16] irrelevance theory suggested that firm value is independent of its financial structures. Subsequently, Modigliani and Miller [18], after taking consideration of corporate tax, underlined the effects and benefits of the tax shield of debt; recognising that leverage can reduce the payment obligations related to corporate tax. The study opined that capital structure is optimal at $100 \%$ debt financing, and the idea that was formulated marked the starting point in laying the foundation for the capital structure debates. According to Myers [15], most of the research on capital structure has focused on the proportions of debt versus equity, as observed on the right-hand side of corporations' balance sheets. Despite this, there is no universal theory of the debt-equity choice and hence several useful conditional theories have been used, and most prominently the trade-off theory, the pecking order hypothesis and the agency theory.

The trade-off theory argues that firms seek debt levels that balance the tax advantages of additional debt against the costs of possible financial distress. The trade-off theory predicts moderate borrowing by tax-paying firms [15]. Conversely, the pecking order hypothesis argues that the firm will borrow, rather than issuing equity, when internal cash flow is not sufficient to fund capital expenditures. Thus, the amount of debt will reflect the firm's cumulative need for external funds [15]. The theory thus assumes that firms follow the financial hierarchy consistent with the Pecking Order Model, relying initially on retained earnings, then debt finance and finally using external equity financing as the last resort [19]. The central friction in the Pecking Order Model of capital structure is the asymmetric information between managers and the less-informed outside investors. Myers and Majluf [20] illustrated how this asymmetry lead firms to prefer internal funds to external funds. The pecking order hypothesis also makes predictions about the maturity and priority structure of debt. Thus securities with the lowest information costs should be issued first, before the firm issues securities with higher information costs. This suggests that short-term debt should ideally be exhausted before the firm issues long-term debt [21]. 
The agency cost theory argues that dangerously high debt levels will increase the value of a firm, despite the threat of financial distress, when a firm's operating cash flow significantly exceeds its profitable investment opportunities [15]. Free cash flow is cash flow in excess of that required to fund all projects that have positive net present values when discounted at the relevant cost of capital [22]. According to Jensen and Meckling [23], an agency relationship is a contract under which the principal engages the agent to perform some service on their behalf which involves delegating some decision making authority to the agent. This creates a problem known as principal-agent problem and it eventually has influence on the ownership structure (capital structure of the firm). As a result, conflicts of interest between shareholders and managers over pay-out policies are especially severe when the organization generates substantial free cash flow. The problem is how to motivate managers to disgorge the cash rather than investing it at below the cost of capital or wasting it on organization inefficiencies. Use of debt can discipline managers to focus more on profitability as it comes with need to pay interest and principal but there is possibility of increased financial distress.

In sum, and according to Myers [15], the trade-off theory emphasizes taxes, the pecking order hypothesis emphasizes differences in information, and the agency cost theory's point of emphasis is free cash flow.

\section{Research on Capital Structure Strategies in Africa and Emerging Markets}

Most of the previous research on capital structure strategies has been conducted in developed economies and studies on the African continent have been limited. Among the few studies in Africa, Naidu [4] conducted a study on Australian and South African firms. Even though the study postulated that the industry effect on aggregate financial leverage was not observed in a sample of firms, the industry effect on other forms of leverage such as short-term leverage were not ruled out. Specifically, this industry influence was observed on South African firms. This finding is of peculiar interest to this study, especially the aspect of country factor influence on aggregate financial leverage being statistically significant, implying that Australian firms and South African firms adopt different leverage strategies. Effectively, context does play a significant role on matters pertaining to capital structure strategies.

Abor and Biekpe [24] examined the determinants of capital structure of SMEs in the context of sub-Saharan Africa. The study argued that these issues have been quite under researched in this part of the world. The study specifically focused on SMEs in Ghana. Firstly, the results showed that short-term debt constituted a relatively high proportion of total debt of Ghanaian SMEs. Secondly, the positive relationships between debt ratios and both age and size suggested that age and size of the firms are very important in influencing SMEs' access to debt finance. In particular, it was found that newer and smaller firms were often discriminated against when applying for external debt finance. Thirdly, the significantly positive relationship between asset structure and long-term debt ratio denoted the fact that asset collateral played an important role in SMEs' access to long-term debt finance.

Meanwhile, Harvey, Lins [25] found that firms in emerging markets had potentially extreme managerial agency problems. The study examined financial statement data and detailed global debt issuance data to test whether debt capital is able to reduce the impact of agency problems. Evidence was that debt creates shareholder value for firms that face potentially high managerial agency costs. Furthermore, cross-sectional tests using financial statement data indicated that debt mitigates the reduction in firm value that accompanies a separation between a management group's control rights and its proportional cash flow ownership [25]. The incremental benefit of debt was found to be concentrated in firms most likely to have overinvestment problems because they have either high levels of assets in place or limited 
growth opportunities. As thus, subsequent internationally syndicated term loans are particularly effective at creating value for these firms.

In summary, these studies highlight that national context and industry factor play a role with regard to capital structure strategies. Further, size and age of the firm and the asset collateral play a significant role in terms of the type of debt financing to use. Notably, newer and smaller firms face more problems with external debt financing and firms with higher asset collateral use more long-term debt financing. With regard to reduction of agency problems, use of debt has been found to provide more value for the firms most likely to have over-investment problems or limited growth opportunities.

\section{Research on Capital Structure Strategies in Transitional Markets}

From the transitional markets perspective, Chen [26] explored the determinants of capital structure of Chinese-listed companies using firm-level panel data and the findings reflected the transitional nature of the Chinese corporate environment. Specifically, certain firm-specific factors that are relevant for explaining capital structure in developed economies are also relevant in China such as business operations following a profit-oriented nature despite China being a central economy as opposed to a market economy.

On the other hand, neither the trade-off model nor the pecking order hypothesis derived from the Western settings provides convincing explanations for the capital choices of the Chinese firms. The astonishing difference was that Chinese firms prefer short-term finance and use lesser long-term debt when compared to firms in developed nations. Interestingly, the capital choice decision of Chinese firms seems to follow a new Pecking order-namely; retained profit, equity, and long-term debt. The reason was that fundamental institutional assumptions underpinning the Western models are not valid in China. Precisely, significant institutional differences and financial constraints in the banking sector in China proved to be the factors influencing firms' leverage decision and they are at least as important as the firm-specific factors [26].

Meanwhile, Huang and Song [27] indicated that as in other countries, leverage in Chinese firms increases with firm size and fixed assets, and decreases with profitability, non-debt tax shields, growth opportunity, managerial shareholdings and correlates with industries. Furthermore, their findings confirmed Chen's finding that unlike in other countries, Chinese firms tend to have much lower long-term debt.

On a similar note, Ang and Jung [28] obtained responses from a sample of large South Korean firms and the results, using both marginal and sensitivity analysis, failed to support the pecking order hypothesis. For example, the results showed that when debt is high, firms are willing to issue shares as the preferred source. Therefore, Ang and Jung [28] found that the South Korean firms in the sample were similar to firms elsewhere, as predicted by trade -off and agency theory because they are sensitive to default probability and taxes, and to a large extent, they are willing to take advantage of information asymmetry.

In sum, these studies, though not extensive, highlight that transitional markets behave differently in terms of capital structure theories and strategies. For example, both trade-off theory and the pecking order theory have been violated in China, as it was found that Chinese firms seem to follow a new Pecking order of retained earnings, equity then debt, and that they tend to have much lower long-term debt. Nonetheless, South Korean firms failed to follow pecking order but were similar to other firms elsewhere in terms of prediction by trade-off and 
agency theory as they were sensitive to both taxes and bankruptcy and managerial inefficiencies.

\section{Research on Capital Structure Strategies in Developed Markets}

Studies in developed nations tend to show some explanatory power of the capital structure theories [20, 29, and 30]. According to Krasker [29], investors interpret stock issues unfavourably, and indeed, interpret larger issues more unfavourably than smaller ones. According to these researchers, this phenomenon provides a rationale for the portfolio approach adopted by many corporations. Specifically, this occurs where the cash generated by some divisions finances the investments of other divisions, and thereby reducing the need for external financing.

De Miguel and Pindado [31] found that transaction costs borne by US firms tend to be inferior to those borne by Spanish firms. The evidence confirmed the impact of some institutional characteristics on capital structure. The results were found consistent with tax and financial distress theories and with the interdependence between investment and financing decisions. Furthermore, they provided additional evidence on the pecking order and free cash flow theories.

Similarly, Frank and Goyal [21] tested the pecking order theory of corporate leverage on a broad cross-section of publicly traded American firms from 1971 to 1998. The study found that contrary to the pecking order theory, net equity issues track the financing deficit more closely than do net debt issues, thus equity was found to be more important than debt in this regard. However, large firms exhibited some aspects of pecking order behaviour, but the evidence was not strong when including conventional leverage factors, nor when analysing the evidence from the 1990s. The study found that over time, the support for the pecking order hypothesis actually declined. More small firms were publicly traded during the 1980s and 1990s than during the 1970s, and since small firms do not follow the pecking order, the overall average moved further from the pecking order hypothesis [21]. However, the time period effect is not entirely due to more small firms in the 1990s because even when attention was constrained to the largest quartile of firms, support for the pecking order theory weakened over time, equity still became more important. Furthermore, financing deficit was less important in explaining net debt issues over time for firms of all sizes.

Baskin [32] sampled a total of 378 US firms from the 1960 Fortune 500, though biased towards large firms. The results of the study indicated that capital structure in practice appears to be somewhat passively determined in response to the need to fund investment with an imperfectly elastic supply of equity from retained earnings. The study findings indicated that firms borrow because they need funds and once asymmetric information places limitations on equity finance, debt tends to become the primary incremental source of funding. The study concluded that established firms normally avoid new equity issues, and borrowing tends to be determined as the residual between desired investment and a relatively inelastic supply of retained earnings. As a result, the pecking order hypothesis was empirically motivated. However, the lack of compelling rational theoretical justification apparently limited its acceptance among the academic mainstream [32].

Hackbarth, Hennessy [33] demonstrated that the trade-off theory is sufficient to explain many stylized facts regarding corporate debt structure. Interestingly, the optimal debt structure for weak firms entails financing exclusively with bank debt. On the other hand, strong firms optimally use a mix of bank and market debt. The trade-off theory also generates predictions consistent with international evidence. For example, in countries in which the bankruptcy 
regime entails soft (tough) enforcement of contractual priority, bank debt capacity is lower (higher), implying greater (lower) reliance on market debt [33].

With regard to the agency theory, Jensen [22] indicated that the theory predicts that takeovers financed with cash and debt will generate larger benefits than those accomplished through exchange of stock. Stock acquisitions tend to be different from debt or cash acquisitions and more likely to be associated with growth opportunities and a shortage of free cash flow. Therefore, the agency cost of free cash flow is consistent with a wide range of data for which there has been no consistent explanation. Opler and Titman [34] paper investigated the determinants of leveraged buyout (LBO) activity by comparing firms that have implemented LBOs to those that have not. As consistent with the free cash flow theory, it was found that firms that initiate LBOs can be characterized as having a combination of unfavourable investment opportunities (low Tobin's q) and relatively high cash flow. Specifically, LBO firms tended to be more diversified than firms which do not undertake LBOs. In addition, firms with high expected costs of financial distress (being those with high research and development expenditures) were found less likely to do LBOs. Meanwhile, Archbold and Lazaridis [35] sent a questionnaire to the Finance Directors of a sample of 219 UK firms, drawn largely from the FTSE 250 and 300 firms listed on the Athens Stock Exchange. The results highlighted that overall both the trade-off model and the pecking order hypothesis are used by firms to guide their decisions over capital structure issues.

Meanwhile, empirical evidence has also suggested that multinational firms use less debt when compared to domestic firms [36-41] as cited in Singh, Davidson [2]. For example, multinational firms face country-specific risks and exchange rate risk which are not faced by domestic firms.

In sum, studies in developed nations show evidence of explanatory power of the three capital structure theories, namely trade-off theory, pecking order theory and free cash flow theory. However, firms that access the capital markets do not seem to follow the pecking order when choosing the type of security to offer [33].

Overall, studies on capital structure are prolific and extensive. As already discussed, they cover a wide range of important areas with a view to unravel factors that influence capital structure and the impact of capital structure on firm performance. While this literature has been insightful in projecting trend analysis on capital structure strategies across the globe, there is limited understanding of the basis for the decision-making rational at a management level. In this respect, the basic question of 'how well defined are capital structure strategies adopted by firms' grossly remains unanswered.

\section{METHODOLOGY}

A survey method using questions adopted from original questionnaire by Graham and Harvey [1] and further adopted in subsequent studies such as Archbold and Lazaridis [35] was used to determine the strategies used by Botswana firms. The study methodology is premised on the presupposition that issues of capital structure become weighty and more pronounced with the increase in the size of the firm, with the largest firms generally being those listed on the stock exchange. It is in this light that firms listed on the Botswana Stock Exchange (BSE) were sampled for the study, and in particular companies that had head offices in the capital city of Botswana, Gaborone. By default, foreign companies listed on the BSE were excluded in the sample. Owing to preliminary or exploratory nature of study, and with the view to cover the diversity of Botswana's economy, a small sample of six firms was chosen on the basis of 
convenience sampling approach. In keeping with the above, the study approach was to conduct in-depth interviews using qualitative tools.

Data was collected using a survey questionnaire that solicited the responses from senior management personnel on strategies adopted by their respective firms in formulating and executing corporate capital structure strategies. In particular, the Chief Financial Officer (CFO) in the respective firms was the targeted respondent. The questions in the questionnaire were purposefully designed to relate the insights of the decision-makers to the three established theories of capital structure; the trade-off theory, the pecking order theory and the agency costs theory. The questionnaire adopted some of the questions from the original 100 questions from Graham and Harvey [1]. The original questionnaire asked questions relating to investment appraisal, cost of capital and dividend policy. However, for the purpose of this study, only questions focused on the debt to equity choices applicable to Botswana firms were selected, in addition to other facets that were found applicable to the study context. Also noteworthy is that this study was conducted as part of a larger study. In part, the aim was to test for the validity, adequacy and clarity of the preliminary questionnaire draft. Also, the preliminary questionnaire required testing on matters relating to the subject matter being investigated, conceptualisation and operationalisation of key variables. This further justified the small sample size.

\section{RESULTS}

In line with the trade-off theory, the study sort to determine firms' preferences for the different types of sources of financing. In particular, respondents were required to state their preference among the three major sources of retained earnings, external equity and debt financing. The results indicated a $16.7 \%$ preference for using retained earnings, $83.3 \%$ preference for using external equity and none $(0 \%)$ preferred using debt financing. Considering that the trade-off theory advocates for the use of debt in the capital structure on the premise of the tax deductibility benefits, which effectively make it cheaper than external equity, the study results disprove this notion.

A trade-off for the benefits accruing to debt increases bankruptcy costs. The study sought to assess the extent to which respondents appreciated these properties of debt. Respondents were asked whether or not the factors of bankruptcy costs associated with debt, tax deductibility of debt and taking advantage of the tax deductibility of debt were imperative in the design of the capital structure strategy of their respective firms. The results, as presented in Table 1, found the trade-off properties of bankruptcy costs and the tax deductibility associated with debt to be imperative considerations by all firms in the design of capital structure strategies.

Table: 1 Trade-off Properties of Debt (Results)

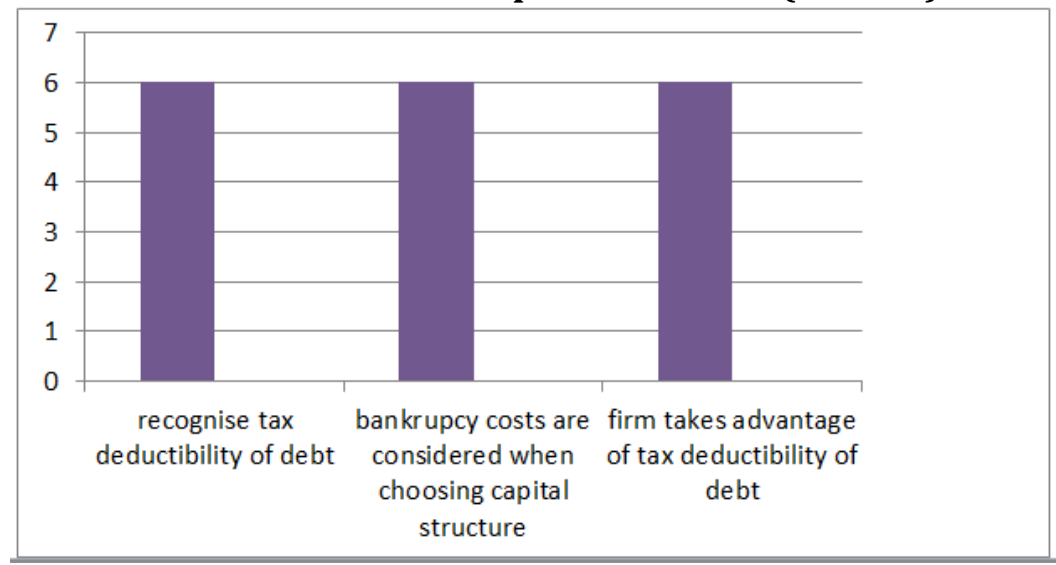


The study findings are suggestive that management is conversant with the connotations and implications of the trade-off theory of capital structure. However, the extent to which these firms deliberately took advantage of the tax deductibility of debt in the design of their capital structure strategies is not apparent. Perhaps the lack of enthusiasm in taking advantage of the tax benefits relating to the use of debt is reminiscent of the difficult economic conditions that have been prevalent in the recent past. The advent of the global financial crisis has increased the risk associated with debt and increased the hurdles associated with its acquisition from financial institutions. In this regard, management would adopt a rather conservative and riskaverse approach in structuring their capital structures. The preference of external equity over retained earnings, however, remains inexplicable using the trade-off theory. This dilemma poses as a subject for further research.

\section{The Pecking-Order Hypothesis}

The pecking order theory is concerned with ranking sources of capital in order of preference and it ascertains that internal finance (or retained earnings) would be ranked highest, followed by debt and finally external equity becoming the least preferred. In sum, a firm would borrow, rather than issue equity, when retained earnings have been exhausted. The study results, as has already been indicated, showed an $83.3 \%$ preference for using external equity, $16.7 \%$ preference for using retained earnings, and $0 \%$ preference for using debt. To further analyse this phenomenon, respondents were asked to rank in the order of preference a wider variety of sources of finance. Respondents were provided with five types of capital sources (bank loan; bond; retained earnings; preference shares; equity shares) and asked to rank them 1-5, with 1 being 'most preferred' and 5 being 'least preferred'. The results indicated that equity financing was the most preferred source of funding. Retained earnings were found to be the second most preferred form of finance. Both forms of debt (loans and bonds) were tied on third place and the hybrid instrument of preference stock ranked as the least preferred source of finance. To the extent that retained earnings were not preferred over external equity, and that equity was preferred over debt, the results contradicted the pecking order hypothesis. While the study did not explore the reasons for preferring external equity over retained earnings and debt, it is not inconceivable that the prevailing debt covenants insisted by lenders may have introduced elements too vile to render debt an attractive option. Reasons for preferring external equity over retained equity are a puzzle and a scope for further research.

\section{The Agency Costs Theory}

The agency costs theory advocates for leverage. It purports that debt commits a firm's current and future resources, and thereby reducing the amount of idle resources, and cash in particular, that would otherwise be prone to the self-indulging behavior of management. In this regard, the firm's capital structure can aid the alignment of the interests of management to that of shareholders. Thus, debt can create an incentive for managers to work harder, consume fewer perquisites and make more optimal investment decisions, and thus maximize shareholders' wealth.

In the study, the respondents were asked if the capital structure formulation strategy of a firm in any way addressed issues related to the agency problem. The results indicated $67.7 \%$ of the responses affirmed that capital structure formation does direct itself in addressing the agency related costs, while $33.3 \%$ of the respondents did not find their strategies aligned to addressing the agency costs. For the purpose of validation of these results, respondents were asked which capital source would be used, between equity and debt, to mitigate agency costs. The results indicated that $80 \%$ of respondents would use debt over equity in addressing and mitigating a firm's agency costs. These results validated the point that management was 
generally knowledgeable of agency costs associated with capital structure strategies and how to mitigate the same.

While results affirmed managements' knowledge of agency costs and mitigation strategies, the capital structure strategies adopted by these firms are not reflective of the actuation of this knowledge. This conclusion is reached in light of the low inclination by respondents to use debt. These findings are suggested of some unidentified factors at play that prevent management from behaving in a manner economically rational enough as to reduce a firm's agency costs. The form and nature of these factors are a matter for further research.

\section{CONCLUSION AND RECOMMENDATIONS}

The paper set out to investigate the different capital structure strategies adopted by firms. The core of the study was to explore the extent to which capital structure strategies of firms were well defined within the scope of established theoretical frameworks. The research questions were developed from the capital structure theories so as to be able to solicit and determine the types of capital structure strategies adopted by different firms and infer the rationale thereof. The results indicated an overall lack of theoretical considerations in the adoption and application of capital structure strategies by management across the sampled listed firms. While most firms preferred using external equity as a financing option, followed by retained earnings, debt was found to be the least preferred financing option. Considering that the tradeoff theory advocates for the use of debt in the capital structure on the premise of the tax deductibility benefits, which effectively makes it cheaper than external equity, the study findings did not conform to the trade-off theory. This is contrary to studies in other African countries, for example, short-term debt constituted a relatively high proportion of total debt of Ghanaian SMEs [7]. Since this study constituted large listed firms, which theoretically, would easily access debt financing, this lack of preference for debt further cements this anomaly.

On the other hand, the pecking order hypothesis dictates that firms would borrow, rather than issue equity, when retained earnings have been exhausted. Again, the results were inconsistent with the theoretical underpinnings of the pecking order hypothesis. A possible explanation for the anomaly could be that such large firms do not appear to tap the capital markets because of a shortfall in internal funds [42]. However, this still remains a puzzle and would need further scrutiny.

In terms of the agency theory, the results affirmed that capital structure formation (in theory) does direct itself in addressing the agency related costs, while their strategies were not aligned to addressing the agency costs. The respondents affirmed that debt was a tool in addressing and mitigating a firm's agency costs. While this outcome validates the point that management are generally knowledgeable of agency costs associated with capital structure strategies, the capital structure strategies adopted by these firms are not reflective of the actuation of this knowledge in their firms' capital structures.

Overall, management was generally knowledgeable of the benefits associated with debt financing, and in particular the tax-deductibility of the cost of debt and reduction of agency costs.

In conclusion, firms in Botswana are not consistent in adopting capital structure strategies that are consistent with established theories of capital structure when making their capital structure decisions. In light of these findings, and the preliminary nature of this study, a more extensive and non-exploratory study that will cover a whole spectrum of firms in Botswana in order to fully assess this phenomenon is recommended. Further, the puzzle that firms in 
Botswana preferred external equity than retained earnings and debt will need special attention. In light of the low inclination by respondents to use debt, this is suggestive of some unidentified factors at play that prevent management from behaving in a manner economically rational enough as to reduce a firm's agency costs. Since the form and nature of these factors was outside the scope of this study, more scrutiny of this enigma in further studies is recommended.

\section{References}

Graham, J.R. and C.R. Harvey, the Theory and Practice of Corporate Finance: Evidence from the Field. Journal of Financial Economics, 2001.60(2): p. 187-243.

Singh, M., W.N. Davidson, and J.-A. Suchard, Corporate Diversification Strategies and Capital Structure The Quarterly Review of Economics and Finance, 2003. 43(1): p. 147-167.

O'Brien, J.P., the Capital Structure Implications of Pursuing a Strategy of Innovation. Strategic Management Journal, 2003. 24(5): p. 415-431.

Naidu, G., Capital Structure Strategies of Australian and South African Firms. Management International Review, 1986. 26(2): p. 52-61.

Bradley, M., G.A. Jarrell, and E. Kim, On the Existence of an Optimal Capital Structure: Theory and Evidence. The Journal of Finance, 1984. 39(3): p. 857-878.

Gatsi, J.G., Capital Structure of Ghanaian Banks: An Evaluation of its Impact on Performance. The IUP Journal of Bank Management, 2012. 11(4): p. 86-99.

Abor, J., Debt Policy and Performance of SMEs: Evidence from Ghanaian and South African Firms. Journal of Risk Finance, 2007. 8(4): p. 364-379.

De Mesquita, J.M. and J.E. CLara, Capital Structure and Profitability: The Brazilian Case, 2003.

Fama, E.F. and K.R. French, Taxes, Financing Decisions and Firm Value. The Journal of Finance, 1998. 53(3): p. 819-843.

Hammes, K., Essays on Capital Structure and Trade Financing. 2003.

Majumdar, S.K. and P. Chhibber, Capital Structure and Performance: Evidence from a Transition Economy on an Aspect of Corporate Governance. Public Choice, 1999. 98(3/4): p. 287-305.

Akintoye, I., Effect of capital structure on firms' performance: the Nigerian experience. European Journal of Economics, Finance and Administrative Sciences, 2008. 10: p. 233-243.

Nerlove, M., Factors Affecting Differences Among Rates of Return on Investments in Individual Common Stocks. The Review of Economics and Statistics, 1968: p. 312-331.

Petersen, M.A. and R.G. Rajan, the Benefits of Lending Relationships: Evidence from Small Business Data. The Journal of Finance, 1994. 49(1): p. 3-37.

Myers, S.C., Capital Structure. The Journal of Economic Perspectives, 2001. 15(2): p. 81-102.

Modigliani, F. and M.H. Miller, the Cost of Capital, Corporation Finance and the Theory of Investment. The American economic review, 1958: p. 261-297.

Durand, D., the Cost of Capital, Corporation Finance, and the Theory of Investment: Comment. The American Economic Review, 1959: p. 639-655.

Modigliani, F. and M.H. Miller, Corporate Income Taxes and the Cost of Capital: A Correction. The American economic review, 1963: p. 433-443.

Chirinko, R.S. and A.R. Singha, Testing Static Tradeoff against Pecking Order Models of Capital Structure: A Critical Comment. Journal of Financial Economics, 2000. 58(3): p. 417-425.

Myers, S.C. and N.S. Majluf, Corporate Financing and Investment Decisions When Firms Have Information That Investors Do Not Have. Journal of financial economics, 1984. 13(2): p. 187-221. 
Frank, M.Z. and V.K. Goyal, Testing the Pecking Order Theory of Capital Structure. Journal of Financial Economics, 2003. 67(2): p. 217-248.

Jensen, M.C., Agency Costs of Free Cash Flow, Corporate Finance and Takeovers. The American Economic Review, 1986: p. 323-329.

Jensen, M.C. and W.H. Meckling, Theory of the Firm: Managerial Behavior, Agency Costs and Ownership Structure. Journal of Financial Economics, 1976. 3: p. 305-360.

Abor, J. and N. Biekpe, How Do We Explain the Capital Structure of SMEs in Sub-Saharan Africa? Evidence from Ghana. . Journal of Economic Studies, 2009. 36(1): p. 83-97.

Harvey, C.R., K.V. Lins, and A.H. Roper, the Effect of Capital Structure When Expected Agency Costs are Extreme. Journal of Financial Economics, 2004. 74(1): p. 3-30.

Chen, J.J., Determinants of Capital Structure of Chinese-listed Companies. Journal of Business Research, 2004. 57(12): p. 1341-1351.

Huang, G. and F.M. Song, the Determinants of Capital Structure: Evidence from China. China Economic Review, 2006. 17(1): p. 14-36.

Ang, J.S. and M. Jung, an Alternate Test of Myers' Pecking Order Theory of Capital Structure: The Case of South Korean Firms. . Pacific-Basin Finance Journal, 1993. 1(1): p. 31-46.

Krasker, W.S., Stock Price Movements in Response to Stock Issues under Asymmetric Information. The journal of Finance, 1986. 41(1): p. 93-105.

Narayanan, M., Debt versus equity under asymmetric information. Journal of Financial and Quantitative Analysis, 1988. 23(1): p. 39-51.

De Miguel, A. and J. Pindado, Determinants of Capital Structure: New Evidence from Spanish Panel Data. Journal of Corporate Finance, 2001. 7(1): p. 77-99.

Baskin, J., an Empirical Investigation of the Pecking Order Hypothesis. Financial Management, 1989: p. 26-35.

Hackbarth, D., C.A. Hennessy, and H.E. Leland, Can the Trade-off Theory Explain Debt Structure? Review of Financial Studies, 2007. 20(5): p. 1389-1428.

Opler, T. and S. Titman, the Determinants of Leveraged Buyout Activity: Free Cash Flow vs. Financial Distress Costs. The Journal of Finance, 1993. 48(5): p. 1985-1999.

Archbold, S. and I. Lazaridis. Capital Structure Decisions and Decision Making: Survey Evidence from the UK and Greece. In 17th Annual Conference, Multinational Finance Society. 2010. Barcelona.

Shapiro, A.C., Financial Structure and Cost of Capital in the Multinational Corporation. Journal of Financial and Quantitative Analysis, 1978. 13: p. 211-226.

Senbet, L.W., International Capital Market Equilibrium and the Multinational Firm Financing and Investment Policies. Journal of Financial and Quantitative Analysis, 1979. 14: p. 455-480.

Michel, A. and I. Shaked, Multinational Corporations vs. Domestic Corporations: Financial Performance and Characteristics. Journal of International Business Studies, 1986. 17: p. 89-100.

Lee, K.C. and C.C.Y. Kwok, Multinational Corporations vs. Domestic Corporations: International Environmental Factors and Determinants of Capital Structure. Journal of International Business Studies, 1988. 19: p. $195-217$.

Burgman, T.A., an Empirical Examination of Multinational Corporate Capital Structure. Journal of International Business Studies, 1996. 27: p. 553-570.

Chen, C.J.P., et al., an Investigation of the Relationship between International Activities and Capital Structure. Journal of Information Systems, 1997. 28: p. 563-577.

Helwege, J. and N. Liang, Is There a Pecking Order? Evidence from a Panel of IPO Firms. Journal of financial economics, 1996. 40(3): p. 429-458. 